WAHANA

AKUNTANSI

Jumal Ilmiah
JURNAL ILMIAH WAHANA AKUNTANSI

Vol 15 (1) 2020, 73-84

http://journal.unj/unj/index.php/wahana-akuntansi

\title{
PENGARUH UKURAN PERUSAHAAN, VARIABILITAS HARGA POKOK PENJUALAN, DAN VARIABILITAS PERSEDIAAN TERHADAP NILAI PERSEDIAAN PADA PERUSAHAAN MANUFAKTUR DAN DAGANG YANG TERDAFTAR DI BURSA EFEK INDONESIA PERIODE 2014-2018
}

Yanti Mumun Maemunah*

(Universitas Buana Perjuangan Karawang )

\section{ARTICLE INFO}

Kata Kunci:

Persediaan, Ukuran perusahan, variabilitas harga pokok penjualan, dan variabilisas persediaan.

\section{ABSTRACT}

Penelitian ini bertujuan untuk mengetahui pengaruh ukuran perusahaan, variabilitas harga pokok penjualan, dan variabilitas persediaan terhadap nilai persediaan pada perusahaan manufaktur dan dagang yang terdaftar di bursa efek indonesia. Populasi dalam penelitian ini adalah perusahaan manufaktur dan perusahan dagang yang terdaftar di Bursa Efek Indonesia (BEI) pada tahun 2014 sampai 2018. Sampel penelitian sebanyak 79 perusahaan manufaktur dan perusahaan dagang yang diperoleh dengan tekknik purposive sampling. Hasil penelitian menunjukan bahwa secara parsial variabel variabilitas harga pokok penjualan tidak mempunyai pengaruh terhadap nilai persediaan,variabilitas persediaan berpengaruh terhadap nilai persediaan, Secara simultan variabel ukuran perusahaan, variabilitas harga pokok penjualan dan variabilitas persediaan berpengaruh signifikan terhadap nilai persediaan pada perusahaan dagang dan perusahaan manufaktur yang terdaftar di Bursa Efek Indonesia (BEI) pada tahun 2014-2018.

Persediaan, Ukuran perusahan, variabilitas harga pokok penjualan, dan variabilisas persediaan.

\footnotetext{
How to Cite:

Yanti Mumun Maemunah. (2020). Pengaruh Ukuran Perusahaan, Variabilitas Harga Pokok Penjualan, dan Variabilitas Terhadap Nilai Persediaan Pada Perusahaan Manufaktur dan Dagang yang Terdaftar di Bursa Efek Indonesia Periode 2014-2018, 15(1), 73-84 https://doi.org/10.21009/wahanaakuntansi/15.1.06
} 


\section{PENDAHULUAN}

Setiap perusahaan baik yang bergerak di bidang manufaktur, perdagangan, maupun perusahaan jasa mempunyai persediaan yang berbeda. Menurut Sutrisno (2012) Perbedaan persediaan untuk masing-masing perusahaan tersebut adalah jenis persediaan. Pada perusahaan dagang, sesuai dengan kegiatannya dimana perusahaan ini melakukan kegiatan membeli barang untuk dijual lagi, maka persediaan utama yang dimiliki berupa persediaan barang dagangan, dan persediaan bahan penolong, serta persediaan perlengkapan kantor. Perusahaan jasa mempunyai persediaan, biasanya dalam bentuk persediaan bahan pembantu atau persediaan habis pakai, termasuk didalamnya kertas, karbon, stempel, tinta, materai, dan persediaan lainnya yang berhubungan dengan jasanya. Sedangkan untuk perusahaan manufaktur mempunyai beberapa macam persediaan utama diantaranya persediaan bahan baku, persediaan bahan setengah jadi dan persediaan barang jadi.

Dari berbagai penjelasan mengenai persediaan yang telah dipaparkan sebelumnya, maka dapat diambil kesimpulan bahwa persediaan merupakan suatu aset terpenting dalam setiap usaha baik usaha dagang maupun manufaktur, terutama dalam perusahaan manufaktur segala aktivitas perusahaan manufaktur terdapat banyak persediaan yaitu persediaan bahan baku, persediaan barang dalam proses dan persediaan barang jadi.

Berdasarkan dari definisi yang telah diuraikan dapat diambil kesimpulan bahwa persediaan sangat berperan penting dalam aktivitas operasional perusahaan, mulai dari masuknya persediaan hingga keluarnya persediaan untuk dijual. Oleh karena itu dalam penetapan metode penilaian persediaan sangat diperlukan dalam penyajian laporan keuangan. Setiap perusahaan menetapkan metode penilaian persediaan yang berbeda sesuai dengan kebijakannya masing-masing perusahaan. Berbeda penerapan penilaian persediaan setiap perusahaan akan menimbulkan dampak berbeda pula. Seperti dalam laporan laba rugi perusahaan yang menggunakan metode FIFO dan yang menggunakan metode rata-rata akan menghasilkan laba yang berbeda. Oleh karena itu penulis menganggap bahwa hal-hal yang mempengaruhi pemilihan metode penilaian persediaan, yaitu Variable Ukuran Perusahaan diambil dari penelitian Vica dan Achmad (2015), variabilitas harga pokok penjualan diambil dari penelitian Alika (2016), dan variabilitas persediaan diambil dari penelitian Kukuh (2012).

Ukuran perusahaan menunjukkan pencapaian operasional suatu perusahaan yang diukur dari nilai penjualan bersih. Variabilitas harga pokok penjualan merupakan variasi nilai harga pokok perusahaan yang mana menentukan tinggi rendahnya laba suatu perusahaan. Sedangkan variabilitas persediaan merupakan variasi dari nilai persediaan suatu perusahaan. Pemilihan metode penilaian akan mempengaruhi variabilitas laba setiap perusahaan. Metode ratarata akan menghasilkan laba yang cenderung stabil dan lebih kecil dibandingkan dengan menggunakan metode FIFO.

Penelitian ini menguji ulang penelitian Vica dan Achmad (2015), penelitian Alika (2016), dan penelitian Kukuh (2012). Penelitian Vica dan Achmad (2015) mengambil sampel dari perusahaan sub sektor perdagangan besar barang produksi dan sub sektor perdagangan eceran periode 2010 - 2013. Penelitian ini menggunakan variabel independen yaitu ukuran perusahaan, 
intensitas persediaan dan variabilitas harga pokok penjualan. Penelitian ini menghasilkan ukuran perusahaan berpengaruh terhadap pemilihan metode akuntansi persediaan. Sedangkan intensitas persediaan dan variabilitas harga pokok penjualan tidak berpengaruh terhadap pemilihan metode akuntansi persediaan.

Penelitian yang dilakukan oleh Alika (2016) dengan mengambil sampel dari perusahaan dagang dan perusahaan manufaktur periode 2012 - 2015. Penelitian ini menggunakan variabel independen yaitu kepemilikan manajerial, variabilitas harga pokok penjualan, ukuran perusahaan variabilitas persediaan, rasio lancar dan leverage. Penelitian ini menghasilkan kepemilikan manajerial dan variabilitas harga pokok penjualan berpengaruh terhadap pemilihan metode akuntansi persediaan. Sedangkan ukuran perusahaan, variabilitas persediaan, rasio lancar dan leverage tidak berpengaruh terhadap pemilihan metode akuntansi persediaan.

Penelitian oleh kukuh (2012) mengambil sampel perusahaan dan perusahaan manufaktur yang terdaftar di Bursa Efek Indonesia periode 2008 - 2010. Penelitian ini menggunakan variabel independen yaitu variabilitas persediaan, variabel besaran perusahaan, ukuran perusahaan, intensitas persediaan, financial leverage, margin laba, rasio lancar, dan variabilitas HPP. Penelitian ini menghasilkan variabilitas persediaan, variabel besaran perusahaan, ukuran perusahaan dan intensitas persediaan berpengaruh terhadap pemilihan berpengaruh metode akuntansi persediaan, sedangkan financial leverage, margin laba, rasio lancar, dan variabilitas HPP tidak berpengaruh terhadap pemilihan metode akuntansi persediaan.

Dari berbagai penelitian diatas, peneliti mengambil variabel independen dari penelitian terdahulu. Variabel yang diambil yaitu ukuran perusahaan diambil dari penelitian Vica dan Achmad (2015), variabilitas harga pokok penjualan diambil dari penelitian Alika (2016), dan variabilitas persediaan diambil dari penelitian Kukuh (2012). Peneliti menggunakan data sekunder, oleh karena itu sampel yang diambil merupakan sampel laporan keuangan dari perusahaan yang terdaftar di Bursa Efek Indonesia. Objek yang diteliti dalam penelitian ini adalah Perusahaan Sektor Perdagangan yang terdaftar di Bursa Efek Indonesia.

Berdasarkan latar belakang yang diuraikan diatas, maka perumusan masalah penelitian ini adalah sebagai berikut :

1. Apakah Ukuran perusahaan berpengaruh terhadap nilai persediaan manufaktur dan dagang yang terdaftar di Bursa Efek Indonesia periode $2014-2018$ ?

2. Apakah variabilitas harga pokok penjualan berpengaruh terhadap nilai persediaan manufaktur dan dagang yang terdaftar di Bursa Efek Indonesia periode 2014-2018?

3. Apakah variabilitas persediaan berpengaruh terhadap nilai persediaan manufaktur dan dagang yang terdaftar di Bursa Efek Indonesia periode 2014- 2018?

4. Apakah ukuran perusahaan, variabilitas harga pokok penjualan, dan variabilitas 
persediaan secara simultan berpengaruh terhadap nilai persediaan perusahaan manufaktur dan dagang yang terdaftar di Bursa Efek Indonesia periode $2014-2018$ ?

Sesuai dengan perumusan masalah yang telah diutarakan, maka tujuan dari penelitian ini untuk mengetahui :

1. Pengaruh ukuran perusahaan terhadap nilai persediaan perusahaan manufaktur dan dagang yang terdaftar di Bursa Efek Indonesia periode 2014 - 2018 ?

2. Pengaruh variabilitas harga pokok penjualan terhadap nilai persediaan perusahaan manufaktur dan dagang yang terdaftar di Bursa Efek Indonesia periode $2014-2018$

3. Pengaruh variabilitas persediaan terhadap nilai persediaan perusahaan manufaktur dan dagang yang terdaftar di Bursa Efek Indonesia periode $2014-2018$

4. Pengaruh secara simultan ukuran perusahaan, variabilitas harga pokok penjualan, dan variabilitas persediaan terhadap nilai persediaan perusahaan manufaktur dan dagang yang terdaftar di Bursa Efek Indonesia periode 2014 2018

\section{Tinjauan Pustaka}

Beberapa penelitian sudah pernah dilakukan untuk meneliti faktor-faktor yang berpengaruh dalam penetapan metode penilaian persediaan. Vica dan Achmad (2015), mengkaji faktor-faktor yang berpengaruh terhadap pemilihan metode akuntansi persediaan pada perusahaan sub sektor perdagangan besar barang produksi dan sub sektor perdagangan eceran yang terdaftar di bursa efek indonesia. Penelitian ini menghasilkan ukuran perusahaan berpengaruh terhadap pemilihan metode akuntansi persediaan. Sedangkan intensitas persediaan dan variabilitas harga pokok penjualan tidak berpengaruh terhadap pemilihan metode akuntansi persediaan. Alika (2016), mengkaji faktor-faktor yang berpengaruh terhadap pemilihan metode akuntansi persediaan. Penelitian ini menghasilkan kepemilikan manajerial dan variabilitas harga pokok penjualan berpengaruh terhadap pemilihan metode akuntansi persediaan. Sedangkan ukuran perusahaan, variabilitas persediaan, rasio lancar dan leverage tidak berpengaruh terhadap pemilihan metode akuntansi persediaan.

Kukuh (2012), mengkaji faktor-faktor yang berpengaruh terhadap pemilihan metode akuntansi persediaan pada perusahaan dagang dan perusahaan manufaktur di bursa efek indonesia. Penelitian ini menghasilkan variabilitas persediaan, variabel besaran perusahaan, ukuran perusahaan dan intensitas persediaan berpengaruh terhadap pemilihan berpengaruh metode akuntansi persediaan, sedangkan financial leverage,margin laba, rasio lancar, dan variabilitas HPP tidak berpengaruh terhadap pemilihan metode akuntansi persediaan.

Rina (2015) mengkaji analisis faktor-fkator yang berpengaruh dalam pemilihan metode akuntansi persediaan pada perusahaan manufaktur yang terdaftar di bursa efek indonesia. Secara parsial, struktur kepemilikan tidak berpengaruh secara signifikan terhadap pemilihan metode persediaan. Ukuran perusahaan, financial leverage, dan margin laba kotor berpengaruh secara signifikan terhadap pemilihan metode persediaan. 
Sedangkan secara simultan Stuktur kepemilikan, ukuran perusahaan, financial leverage, dan margin laba kotor berpengaruh terhadap pemilihan metode persediaan.

Shoffa (2012) mengkaji faktor-fkator yang berpengaruh dalam pemilihan metode akuntansi persediaan pada perusahaan manufaktur yang terdaftar di bursa efek indonesia. Berdasarkan pengujian dengan regresi logistik, diketahui bahwa variabel yang berpengaruh secara signifikan terhadap pemilihan metode penilaian persediaan pada penelitian ini adalah variabel ukuran perusahaan, sedangkan variabel leverage, likuiditas dan laba sebelum pajak tidak berpengaruh secara signifikan.

\section{Gambar 2.1}

Kerangka Pemikiran
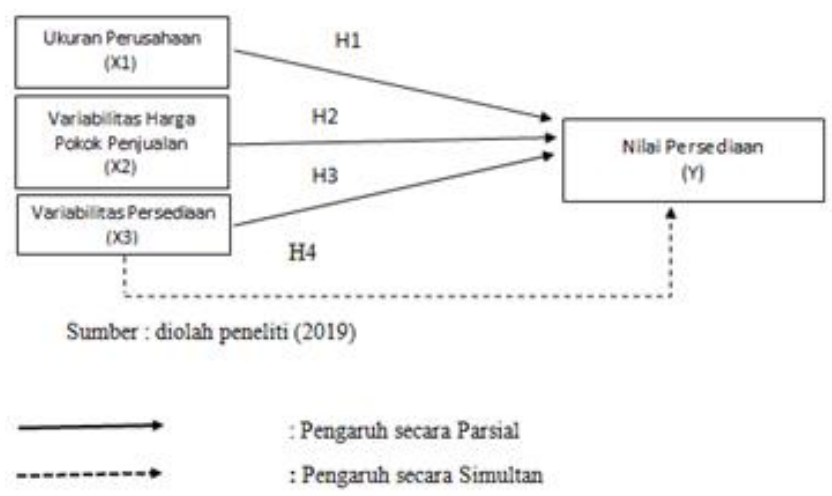

\section{Rumusan Hipotesis Penelitian}

Pengaruh Ukuran Perusahaan Terhadap Nilai Persediaan

Berdasarkan hasil penelitian dari Vica dan Achmad (2015) menyatakan bahwa ukuran perusahaan berpengaruh terhadap penilaian persediaan. Dengan demikian hipotesis yang diajukan

H1 =Ukuran perusahaan berpengaruh terhadap nilai persediaan pada perusahaan dagang dan perusahaan manufaktur yang terdaftar di Bursa Efek Indonesia 2014-2018.
Pengaruh Variabilitas Harga Pokok Penjualan Terhadap Nilai Persediaan

Berdasarkan hasil penelitian variabilitas harga pokok penjualan diambil dari penelitian Alika (2016) menyatakan bahwa ukuran perusahaan berpengaruh terhadap penilaian persediaan. Dengan demikian hipotesis yang diajukan :

$\mathrm{H} 2$ = Variabilitas harga pokok penjualan berpengaruh terhadap nilai persediaan pada perusahaan dagang dan perusahaan manufaktur yang terdaftar di Bursa Efek Indonesia 20142018.

Pengaruh Variabilitas Persediaan Terhadap Nilai Persediaan

Berdasarkan hasil penelitian variabilitas harga pokok penjualan diambil dari penelitian Kukuh (2012). Menyatakan bahwa ukuran perusahaan berpengaruh terhadap penilaian persediaan. Dengan demikian hipotesis yang diajukan :

$\mathrm{H} 3=$ Variabilitas persediaan berpengaruh terhadap nilai persediaan pada perusahaan dagang dan perusahaan manufaktur yang terdaftar di Bursa Efek Indonesia 2014-2018.

\section{Metodologi Penelitian}

Penelitian ini menggunakan metode dokumentasi dan kepustakaan yang diperoleh dari data laporan keuangan perusahaan manufaktur dan perusahaan dagang yang terdaftar di BEI tahun 2014 -2018. Menurut sifatnya, data dalam penelitian ini termasuk data kuantitatif yang

Populasi

Populasi adalah wilayah generalisasi yang terdiri atas objek atau subjek yang mempunyai kualitas dan karakteristik tertentu yang ditetapkan oleh peneliti untuk dipelajari dan kemudian ditarik kesimpulan (sugiyono, 2015:80). 
Populasi yang akan digunakan dalam penelitian ini adalah seluruh perusahaan dagang dan manufaktur yang terdaftar di Bursa Efek Indonesia (BEI) periode tahun 2014-2018, yaitu sebanyak 170 perusahaan.

Sampel

Sampel adalah bagian dari jumlah dan karakteristik yang dimiliki oleh populasi tersebut, dan untuk sampel yang diambil dari populasi harus betul-betul representative (mewakili). Sampel yang dipilih dalam penelitian ini menggunakan teknik sampling. Teknik sampling yang digunakan dalam penelitian ini non probality sampling yaitu dengan sampling purposive. Menurut sugiyono (2015.85) Sampling purposive adalah teknik penentuan sampel dengan pertimbangan tertentu. Ada beberapa pertimbangan yang ditetapkan dalam penelitian ini sebagai berikut:

1. Perusahaan dagang dan manufaktur yang terdaftar di Bursa Efek Industri (BEI) 2014 -2018 .

2. Melaporkan laporan keuangan perusahaan secara berturut-turut pada tahun 20142018.

3. Perusahaan yang memperoleh Laba secara konsisten selama periode pengamatan.

4. Perusahaan yang menggunakan satu metode dalam penilaian persediaannya selama periode penelitian.

Berdasarkan pertimbangan yang telah ditentukan tersebut, maka diperoleh sampel sebanyak 79 perusahaan dari jumlah populasi 170 perusahaan dagang dan manufaktur .

Adapun perhitungan sampel dalam penelitian ini adalah sebagai berikut:
Tabel 3.1

Perhitungan Sampel

\begin{tabular}{|l|l|l|}
\hline No & Keterangan & Jumlah \\
\hline 1 & $\begin{array}{l}\text { Perusahaan dagang dan manufaktur yang } \\
\text { terdaftar di Bursa Efek Industri (BEI) 2014- } \\
2018\end{array}$ & 170 \\
\hline 2 & $\begin{array}{l}\text { Perusahaan secara berturut-turut pada tahun } \\
2014-2018 \quad \text { tidak melaporkan laporan } \\
\text { keuangan }\end{array}$ & $(43)$ \\
\hline 3 & $\begin{array}{l}\text { Perusahaan yang tidak memperoleh Laba } \\
\text { secara konsisten selama periode pengamatan }\end{array}$ & $(38)$ \\
\hline 4 & $\begin{array}{l}\text { Perusahaan yang tidak menggunakan satu } \\
\text { metode dalam penilaian persediaannya. }\end{array}$ & $(10)$ \\
\hline Jumlah & 79 \\
\hline
\end{tabular}

Sumber : www.idx.co.id (diolah oleh Peneliti, 2019)

\section{Hasil dan Diskusi}

Berdasarkan hasil statistik deskripsi menunjukan nilai $\mathrm{N}=79$ data, sampel pada perusahaan manufaktur dan perusahaan dagang yang terdaftar di BEI tahun 2014 -2018 dengan nilai rata-rata HPP sebesar 0,0526 dengan standar deviasi sebesar ,07290. Nilai rata-rata variablilitas persediaan ,0546 dengan standar deviasi 0,05885 . Dan nilai rata-rata persediaan sebesar 0,8481 dengan standar deviasi sebesar 0,36122.

\section{Uji Asumsi Klasik}

Tabel 4.2

\section{Hasil Uji Normalitas Data}

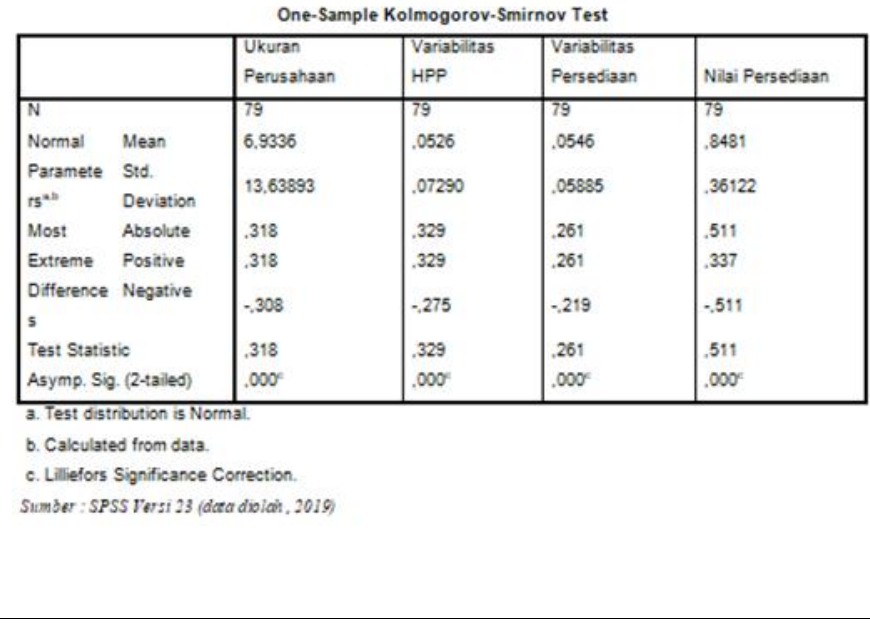


Berdasarkan hasil uji normalitas pada tabel diatas setelah dilakukan normaslitas outlier dapat dilihat nilai probabilitas semua variabel signifikasi (Asymp Sig (2-tailed) sebesar 0,200. Maka dapat disimpulkan bahwa data berdistribusi normal dan model regresi memenuhi asumsi normalitas karena memiliki nilai signifikansi diatas 0,05.

\section{Uji Heterokedastisitas}

Tabel 4.4

\section{Hasil Uji Heterokedastisitas}

Coefficients

\begin{tabular}{|c|c|c|c|c|c|}
\hline \multirow[b]{2}{*}{ Model } & \multicolumn{2}{|c|}{ Unstandardzed Coefficierts } & \multirow{2}{*}{$\begin{array}{l}\text { Standardized } \\
\text { Coefficients } \\
\text { Beta }\end{array}$} & \multirow[b]{2}{*}{$t$} & \multirow[b]{2}{*}{ Sig. } \\
\hline & $B$ & Std. Error & & & \\
\hline (Constant) & 986 & .112 & & 8,809 &, 000 \\
\hline Ukuran & .006 & .006 & , 106 & .785 & 436 \\
\hline HPP & -.727 & 1,966 &,- 051 &,- 370 &, 713 \\
\hline Persediasan & $-1,510$ & 1,870 &,- 110 &,- 808 & .423 \\
\hline
\end{tabular}

Sumber : SPSS Versi 23

Berdasarkan hasil uji glesjer yang dilakukan semua variabel mengalami signifikan, ukuran perusahaan menunjukkan niai signifikan sebesar 0,436, variabilitas harga pokok penjualan menunjukkan nilai signifikan sebesar 0,713 , dan variabilitas persediaan menunjukkan nilai sebesar 0,423. Maka dapat disimpulkan bahwa penelitian ini tidak terjadi heteroskedastisitas dan memenuhi asumsi karena memiliki nilai signifikansi diatas 0,05

\section{Uji Multikolinearitas}

Berdasarkan hasil uji dari ukuran perusahaan sebesar 0,164, variabilitas harga pokok penjualan sebesar 0,033 dan variabilitas persediaan sebesar 0,24 . Nilai tolerance variabel ukuran perusahaan dapat disimpulkan bahwa nilai tolerance bebas multikolinearitas, karena nilai tolerance diatas 0,1, sedangkan variabilitas harga pokok penjualan dan variabilitas persediaan tidak tolerance karena memiliki nilai $<0,1$. Dapat disimpulkan bahwa variabel ukuran perusahaan terjadi multikolinearitas.

\section{Tabel 4.5}

\section{Hasil Uji Multikolinearitas}

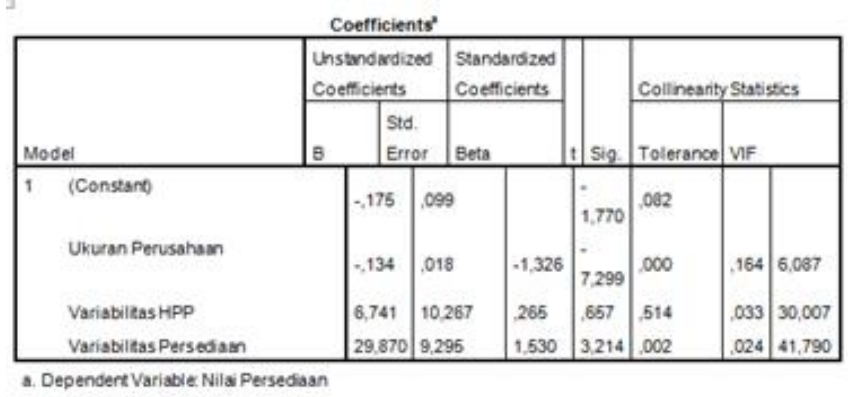

Sumber : SPSS Versi 23, data diolah (2019)

\section{Uji Autokorelasi}

\section{Tabel 4.6}

Hasil Uji Autokorelasi

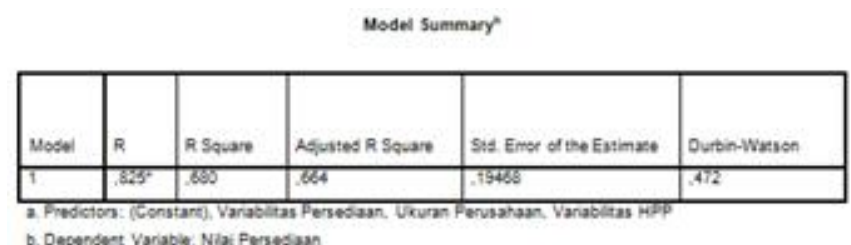

Sumber : SPSS Versi 23 (data, diolah 2019)

Berdasarkan hasil dari pengujian uji autokorelasi tentang pengaruh ukuran perusahaan, variabilitas harga pokok penjualan dan variabilitas persediaan terhadap nilai persediaan pada perusahaan manufaktur dan perusahaan dagang, diketahui nilai Durbin Watson sebesar 0,472 dimana nilai tersebut terletak diantara -2 sampai +2 . Jadi dapat disimpulkan bahwa tidak terjadi autokorelasi pada penelitian ini.

\section{Hasil Uji Regresi Linear Berganda}

hasil uji regresi linier berganda mengenai ukuran perusahaan, variabilitas harga pokok penjualan dan variabilitas persediaan berpengaruh terhadap 
nilai persediaan, maka dapat disajikan persamaan regresi sebagai berikut :

$$
\begin{aligned}
& \mathrm{Y}=a+\beta_{1} X_{1}+\beta_{2} X_{2}+\beta_{3} X_{3}+\mathrm{e} \\
& \mathrm{Y}=-0,175+-1,326^{X_{1}}+0,265^{X_{2}}+1,530 X_{2} \\
& +\mathrm{e}
\end{aligned}
$$

\section{Tabel 4.7}

Hasil Uji Analisis Regresi Lineal Berganda

Coefficients ${ }^{*}$

\begin{tabular}{|l|l|l|l|l|l|}
\hline \multirow{4}{*}{ Model } & \multicolumn{2}{|l|}{$\begin{array}{l}\text { Unstandardized } \\
\text { Coefficients }\end{array}$} & $\begin{array}{l}\text { Standardize } \\
\text { d Coefficients }\end{array}$ & & \\
\cline { 2 - 5 } & B & Std. Error & Beta & t & Sig \\
\hline (Constant) &,- 175 &, 099 & & $-1,770$ &, 082 \\
Ukuran Perusahaan &,- 134 &, 018 & $-1,326$ & $-7,299$ &, 000 \\
Variabilitas HPP & 6,741 & 10,267 &, 265 &, 657 &, 514 \\
Variabilitas Persediaan & 29,870 & 9,295 & 1,530 & 3,214 &, 002 \\
\hline
\end{tabular}

Sedangkan nilai intersif koefisien dari masing-masing variabel diantaranya ukuran perusahaan $\left({ }^{X_{1}}\right)$, variabilitas harga pokok penjualan $\left(X_{2}\right)$, variabilitas persediaan $\left(X_{3}\right)_{2}$ nilai persediaan (Y) dalam persamaan diatas dapat dijelaskan sebagai berikut:

a. Konstanta sebesar $-0,175$ artinya jika variabel independen dianggap konstan, maka nilai persediaan yang dihasilkan sebesar 0,175 .

b. Koefisien regresi ukuran perusahaan $\left({ }^{X_{1}}\right)$ sebesar $-1,326$ bernilai negatif. Hal ini menunjukkan pada nilai persediaan yang dihasilkan sebesar -1,326.

c. Koefisien regresi ukuran perusahaan mengalami penurunan sebesar Rp 1 variabel, maka nilai persediaan akan mengalami penurunan sebesar Rp-1,326 dengan asumsi variabel independen lain bernilai tetap.

d. Koefisien regresi variabilitas harga pokok penjualan $\left(X_{2}\right)$ sebesar 0,265 bernilai positif. Hal ini menunjukkan pada saat variabilitas harga pokok penjualan mengalami kenaikan sebesar Rp 1 variabel, maka nilai persediaan akan mengalami kenaikan sebesar Rp 0,265 dengan asumsi variabel independen lain bernilai tetap.

e. Koefisien regresi variabilitas persediaan ( $X_{2}$ ) sebesar 0,265 bernilai positif. Hal ini menunjukkan pada saat variabilitas persediaan mengalami kenaikan sebesar $\mathrm{Rp}$ 1 variabel, maka nilai persediaan akan mengalami kenaikan sebesar Rp 0,265 dengan asumsi variabel independen lain bernilai tetap. Ketika variabilitas persediaan mengalami kenaikan, maka jumlah pencapaian nilai persediaan akan mengalami kenaikan. Begitu juga pada saat variabilitas persediaan mengalami penurunan maka jumlah pencapaian nilai persdiaan akan turun.

\section{Pengujian Hipotesis}

\section{Uji Koefisien Determinasi ( $\left.\mathbf{R}^{2}\right)$}

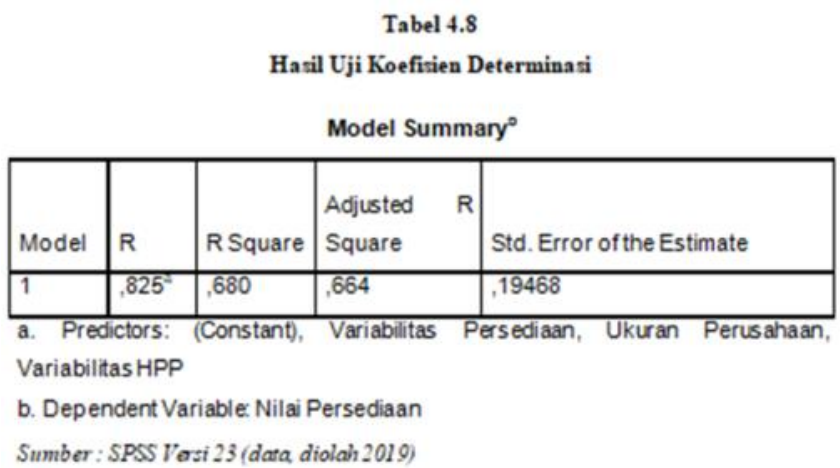


$\mathrm{KD}=0,825^{2} \times 100 \%=68,06 \%$

Nilai koefisien determinasi (R2) adalah sebesar $68,06 \%$ menunjukan bahwa kemampuan variabel independen yaitu ukuran perusahaan, variabilitas harga pokok penjualan dan variabilitas persediaan sebesar $68,06 \%$, sedangkan sisanya sebesar $(100 \%-68,06 \%=31,49 \%)$ dipengaruhi oleh variabel lain yang belum diteliti dalam penelitian ini.

\section{Uji Signifikan Parameter Individual (Uji Statistik t)}

Tabel 4.9

Hasil Uji Statistik (Uji-t)

\begin{tabular}{|c|c|c|c|c|c|}
\hline \multicolumn{6}{|c|}{ Coefficients ${ }^{2}$} \\
\hline \multirow[b]{2}{*}{ Model } & \multicolumn{2}{|c|}{$\begin{array}{l}\text { Unstandardized } \\
\text { Coefficients }\end{array}$} & \multirow{2}{*}{\begin{tabular}{|l}
$\begin{array}{l}\text { Standardized } \\
\text { Coefficients }\end{array}$ \\
Beta
\end{tabular}} & \multirow[b]{2}{*}{$t$} & \multirow[b]{2}{*}{ Sig. } \\
\hline & $B$ & $\begin{array}{l}\text { Std. } \\
\text { Error }\end{array}$ & & & \\
\hline 1 (Constant) &,- 175 & .099 & & $-1,770$ &., 082 \\
\hline Ukuran Perusahaan &,- 134 &, 018 & $-1,326$ & $-7,299$ & .000 \\
\hline Variabilitas HPP & 6,741 & 10,267 & .265 & .657 & .514 \\
\hline Variabilitas Persediaan & 29,870 & 9,295 & 1,530 & 3,214 & .002 \\
\hline
\end{tabular}

Sumber : SPSS Vasi 23 (data diolah 2019)

Nilai signifikan dari ukuran perusahaan sebesar 0,00 lebih kecil dari 0,05 berpengaruh signifikan terhadap nilai persediaan. Nilai signifikan variabel bebas harga pokok penjualan sebesar 0,514 lebih besar dari 0,05 tidak berpengaruh signifikan terhadap nilai persediaan. Sehingga daapt disimpulkan bahwa variabel bebas ukuran perusahaan berpengaruh signifikan terhadap nilai persediaa.

\section{Uji Signifikan Simultan (Uji Statistik F)}

Tabel 4.10

Hasil Uji Statistik F

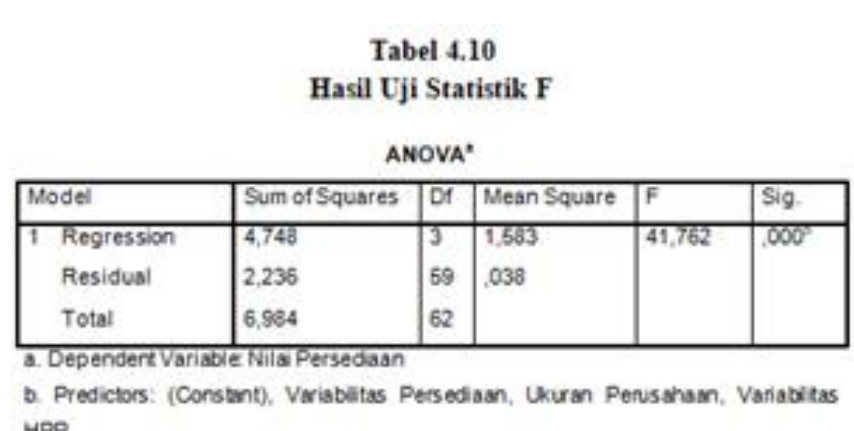

HPP

Nilai $f_{\text {hitung }}$ sebesar 41,762 dan hasil $F_{\text {tabel }}$ sebesar $2,50(41,762>2,50)$ dengan tingkat signifikan $0,000<0,05$, dengan tingkat signifikan 0.000 lebih kecil dari 0,05, sehingga disimpulkan bahwa $\mathrm{H}_{0}$ ditolak dan $\mathrm{H}_{\mathrm{a}}$ diterima, dengan kata lain bahwa secara simultan ukuran perusahaan, variabilitas harga pokok penjualan dan variabilitas persediaan berpengaruh positif dan signifikan terhadap nilai persediaan.

Berikut ini adalah hasil pembahasan mengenai pengaruh ukuran perusahaan $\left(\mathrm{X}_{1}\right)$, variabilitas harga pokok penjualan $\left(\mathrm{X}_{2}\right)$, variabilitas persediaan $\left(\mathrm{X}_{3}\right)$ terhadap nilai persediaan $(Y)$.

Pengaruh Ukuran Perusahaan Terhadap Nilai Persediaan Pada Perusahaan Manufaktur dan Perusahaan Dagang Yang Terdaftar di BEI periode 2014-2018

Berdasarkan hasil uji parsial (uji-t) dalam penelitian ini adalah bahwa ukuran perusahaan berpengaruh terhadap nilai persediaan pada perusahaan manufaktur dan perusahaan dagang yang terdaftar di BEI periode 2014-2018. Hasil pengujian untuk uji parsial (uji -t) adalah nilai $t_{\text {hitung }}$ sebesar -7,299 dan nilai $t_{\text {tabel }} 1,99254$ dengan nilai signifikasi sebesar 0,000 . Nilai signifikasi sebesar $0,000<0,05$. 
Kesimpulan dari hipotesis pertama $\mathrm{H}_{\mathrm{a} 1}$ diterima dan $\mathrm{H}_{\mathrm{o}}$ ditolak, dengan kata lain bahwa terdapat pengaruh signifikan antara ukuran perusahaan $\left(\mathrm{X}_{1}\right)$ terhadap nilai persediaan $(\mathrm{Y})$. Hal ini membuktikan bahwa adanya kesesuaian antara teori dengan hasil penelitian. Perusahaan besar cenderung memilih metode persediaan yang menghasilkan nilai persediaan yang stabil karena akan menurunkan laba sehingga dapat meminimalisir pembayaran pajak, dan sebaliknya, perusahaan kecil akan memilih metode persediaan yang menghasilkan nilai persediaan yang rendah karena akan menaikkan laba untuk memberikan gambaran perusahaan yang baik sehingga memungkinkan dana pinjaman dari kreditor akan meningkat.

\section{Pengaruh Variabilitas Harga Pokok Penjualan Terhadap Nilai Persediaan Pada Perusahaan Manufaktur dan Perusahaan Dagang Yang Terdaftar di BEI periode 2014- 2018}

Berdasarkan hasil uji parsial (uji-t) dalam penelitian ini adalah bahwa variabilitas harga pokok penjualan tidak berpengaruh terhadap nilai persediaan pada perusahaan manufaktur dan perusahaan dagang yang terdaftar di BEI periode 2014-2018. Hasil pengujian untuk uji parsial (uji -t) adalah nilai $t_{\text {hitung }}$ sebesar -0, ,657 dan nilai $t_{\text {tabel }}$ sebesar 1,99254 dengan nilai signifikasi sebesar 0,514. Nilai signifikan sebesar $0,514>0,05$. Kesimpulan dari hipotesis pertama $\mathrm{H}_{\mathrm{a} 1}$ ditolak dan $\mathrm{H}_{\mathrm{o} 1}$ diterima, dengan kata lain bahwa tidak terdapat pengaruh signifikan antara variabilitas harga pokok penjualan $\left(\mathrm{X}_{2}\right)$ terhadap nilai persediaan $(\mathrm{Y})$. Hal ini membuktikan bahwa tidak adanya kesesuaian antara teori dengan hasil penelitian. Secara umum variabilitas harga pokok penjualan tidak terlalu mempengaruhi nilai persediaan, karena tidak sedikit perusahaan yang memilih untuk menghasilkan nilai persediaan yang rendah karena untuk meningkatkan laba yang dihasilkan.

\section{Pengaruh Variabilitas Persediaan Terhadap Nilai Persediaan Pada Perusahaan Manufak- tur dan Perusahaan Dagang Yang Terdaftar di BEI periode 2014-2018}

Berdasarkan hasil uji parsial (uji-t) dalam penelitian ini adalah bahwa variabilitas persediaan berpengaruh terhadap nilai persediaan pada perusahaan manufaktur dan perusahaan dagang yang terdaftar di BEI periode 2014-2018. Hasil pengujian untuk uji parsial (uji -t) adalah nilai $t_{\text {hitung }}$ sebesar sebesar 3,214 dan nilai $t_{\text {tabel }} 1,99254$ dengan nilai signifikasi sebesar 0,002. Nilai signifikasi sebesar 0,002< 0,05 . Kesimpulan dari hipotesis pertama $\mathrm{H}_{\mathrm{a} 1}$ diterima dan $\mathrm{H}_{\mathrm{o}}$ ditolak, dengan kata lain bahwa terdapat pengaruh signifikan antara variabilitas persediaan $\left(\mathrm{X}_{3}\right)$ terhadap nilai persediaan $(\mathrm{Y})$. Hal ini membuktikan bahwa adanya kesesuaian antara teori dengan hasil penelitian. Apabila semakin kecil variasi nilai persediaan maka variasi terhadap labanya juga akan semakin kecil. Begitu pula sebaliknya, apabila variasi nilai persediaan semakin besar maka laba sebuah perusahaan juga akan besar. 
Pengaruh Ukuran Perusahaan, Variabilitas Harga Pokok Penjualan, dan Variabilitas Persediaan Terhadap Nilai Persediaan Pada Perusahaan Manufaktur dan Perusahaan Dagang Yang Terdaftar di BEI periode 20142018

Berdasarkan hasil uji secara simultan (uji-f) dalam penelitian ini adalah bahwa ukuran perusahaan, variabilitas harga pokok penjualan dan variabilitas persediaan berpengaruh terhadap nilai persediaan pada perusahaan manufaktur dan dagang yang terdaftar di BEI periode 2014-2018. Hasil pengujian untuk uji simultan (uji -f) adalah nilai $f_{\text {hitung }}$ sebesar sebesar 41,762 dan nilai $f_{\text {tabel }} 2,50$ dengan nilai signifikasi sebesar 0,000 . Nilai signifikasi sebesar $0,000<0,05$. Kesimpulan dari hipotesis pertama $\mathrm{H}_{\mathrm{a} 4}$ diterima dan $\mathrm{H}_{\mathrm{o} 4}$ ditolak, dengan kata lain bahwa terdapat pengaruh signifikan antara ukuran perusahaan $\left(\mathrm{X}_{1}\right)$, variabilitas harga pokok penjualan $\left(\mathrm{X}_{2}\right)$ dan variabilitas persediaan $\left(\mathrm{X}_{3}\right)$ terhadap nilai persediaan $(\mathrm{Y})$. Hal ini membuktikan bahwa adanya kesesuaian antara teori dengan hasil penelitian.

\section{Kesimpulan}

Berdasarkan hasil penelitian dan pembahasan mengenai pengaruh ukuran perusahaan, variabilitas harga pokok penjualan dan variabilitas persediaan terhadap nilai persediaan pada perusahaan manufaktur dan perusahaan dagang yang terdaftar di Bursa Efek Indonesia tahun 20142018, maka peneliti mengambil beberapa kesimpulan sesuai rumusan masalah yang dicari sebagai berikut :

1. Ukuran perusahaan berpengaruh signifikan terhadap nilai persediaan pada manufaktur yang terdaftar di Bursa Efek Indonesia periode 2014-2018. Menunjukan bahwa Perusahaan besar cenderung memilih metode persediaan yang menghasilkan nilai persediaan yang stabil karena akan menurunkan laba sehingga dapat meminimalisir pembayaran pajak, dan sebaliknya, perusahaan kecil akan memilih metode persediaan yang menghasilkan nilai persediaan yang rendah karena akan menaikkan laba . untuk memberikan gambaran perusahaan yang baik sehingga memungkinkan dana pinjaman dari kreditor akan meningkat.

2. Variabilitas harga pokok penjualan tidak berpengaruh terhadap nilai persediaan pada perusahaan dagang dan perusahaan manufaktur yang terdaftar di Bursa Efek Indonesia periode 2014-2018 Hal ini menunjukkan Secara umum variabilitas harga pokok penjualan tidak terlalu mempengaruhi nilai persediaan, karena tidak sedikit perusahaan yang memilih untuk menghasilkan nilai persediaan yang rendah karena untuk meningkatkan laba yang dihasilkan.

3. Variabilitas persediaan berpengaruh signifikan terhadap nilai persediaan pada perusahaan dagang dan perusahaan manufaktur yang terdaftar di Bursa Efek Indonesia periode 2014-2018. Hal ini menunjukkan Apabila semakin kecil variasi nilai persediaan maka variasi terhadap labanya juga akan semakin kecil. Begitu pula sebaliknya, apabila variasi nilai persediaan semakin besar maka laba 
sebuah perusahaan juga akan besar.

4. Berdasarkan hasil pengujian secara simultan (Uji-F) ukuran perusahaan, variabilitas harga pokok penjualan dan variabilitas persediaan berpengaruh secara bersama-sama (simultan) dengan nilai signifikansi sebesar $0,000<0,05$. Jadi dapat disimpulkan ukuran perusahaan, variabilitas harga pokok penjualan dan variabilitas persediaan berpengaruh signifikan terhadap nilai persediaan pada perusahaan dagang dan perusahaan manufaktur yang terdaftar di Bursa Efek Indonesia periode 2014-2018. Besar pengaruh kedua variabel secara simultan sebesar $68,06 \%$ dan sisanya dipengaruhi oleh variabel lain yang tidak peneliti gunakan dalam penelitian ini.

\section{DAFTAR PUSTAKA}

Brigham dan Huston. 2010. Dasar-dasar Manajemen Keuangan Buku 1 (Edisi 11). Jakarta : Salemba Empat.

Chaerulisa, Vica Novica dan Tjahjono, Achmad. 2015. Analisis Faktor-Faktor Yang Berpengaruh Terhadap Pemilihan Metode Akuntansi Persediaan Pada Perusahaan Sub Sektor Perdagangan Besar Barang Produksi Dan Sub Sektor Perdagangan Eceran Yang Terdaftar Di Bursa Efek Indonesia (BEI). Jurnal kajian bisnis.Yogyakarta.

Ghozali, Imam. 2011. Aplikasi Analisis Multivariate dengan Program IBM SPSS 19. Semarang : Badan Penerbit Universitas Diponegoro.

Hanum, Alika Lathifa.2016 Analisis FaktorFaktor Yang Berpengaruh Terhadap Pemilihan Metode Akuntansi Persediaan.
Skripsi. Akuntansi Fakultas Ekonomi dan

Bisnis. Universitas Muhammadiyah Yogyakarta

Marwah, Shofaa. 2012 Analisis Faktor-Faktor Yang Mempengaruhi Pemilihan Metode Penilaian Persediaan Pada Perusahaan Manufaktur Yang Terdaftar Di Bei Tahun 2007-2010. Dalam jurnal Akuntansi dan Bisnis

Nurbatin, Defia. Sari, Ati Retna dan Setiyowati, Supami Wahyu. 2018. Akuntansi Keuangan dalam Perspektif IFRS dan SAK -ETAP Jakarta: Mitra Wacana Media

Priyatno, Duwi. 2012. Cara Kilat Belajar Analisa

Data Dengan SPSS 20. Yogyakarta. CV Andi

Rudianto. 2012. Pengantar Akuntansi. Jakarta : Erlangga.

Setiyanto, Kukuh Budi. 2012. Analisis Faktor-

Faktor Yang Berpengaruh Terhadap Pemilihan Metode Akuntansi Persediaan. Skripsi. Akuntansi. Universitas Diponegoro Sugiyono.2015. Metode Penelitian Kuantitatif Kualitatif dan R\&D . bandung: Alfabeta Sutrisno. 2013. Manajemen Keuangan. Yogyakarta : Ekonisia 